\title{
HYDROFRACTURING IN THE DEVELOPMENT OF GROUNDWATER RESOURCES IN THESOUTHERN PART OF THE VOLTA REGION OF GHANA
}

\author{
E. B. Asare \\ Water Research Institute (CSIR) \\ P. O. BoxM32, Accra - Ghana
}

\begin{abstract}
The yield of marginal and sometimes dry wells may be improved by the application of hydrofracturing methods. Hydrofracturing is the technique by which potential and lor existing fractures and cracks within a geologic formation are forced to open further by using high pressures induced through water within the well profile so that the increased crack opening will induce increased water flow into the well. When this technique was applied to the development of wells for the supply of drinking water to communities in the Akatsi, Adidome and Ho Districts in the Volta Region, the results were dramatic; well yields increased several fold and in some cases by more than 1,000\% and made it possible for even dry and marginalyield wells, which otherwise would have been declared unproductive and abandoned to be developed for hand pump installation. Out of 37 boreholes to which the hydrofracturing technique was applied, as many as 35 were made productive and are now the sources of water supply for the communities in which they are located
\end{abstract}

Keywords: boreholes, cracks, groundwater, hydrofracturing, marginal and dry wells, specific capacity, yield

\section{INTRODUCTION}

In some parts of the Volta Region, potable water is being supplied to communities through borehole systems developed under the Volta Region Water Supply and Sanitation (VRWSS) project. Even though the project has generally been successful in making it possible for several communities in the region to enjoy clean water, it has not been without problems; the incidence of dry wells and wells with low or uneconomic yield which required some of the boreholes drilled under the project to be abandoned threatened the project's viability.

To reduce the incidence of abandonment of wells to the minimum, the VRWSS project decided to apply hydro-fracturing method to all dry and / or marginal wells in order to increase their yield. Wells falling under this category were defined by the project as those with yields below $13.51 / \mathrm{min}$. Hydro-fracturing is a technique by which potential or existing fractures and fissures within a geologic formation which serves as a groundwater aquifer are forced to open further by using high pressures induced in water at various depths within the borehole profile. The increased fracture opening then induces more water to flow from the formation into the well.
When the hydro-fracturing technique was applied to the development of wells in Akatsi, Adidome and Ho Districts in Volta Region, the results were dramatic; dry wells and wells with marginal yields which otherwise would have been declared unproductive and abandoned because of their uneconomic yields increased in yield several fold and justified hand pump installation on them for water abstraction. Out of 37 boreholes to which the hydrofracturing technique was applied, as many as 35 were made productive and are now the main sources of drinking water for the communities in which they are located.

In this paper, the technique of hydrofracturing as was applied to the development of the wells in the three districts are presented and discussed. The objective is to present the usefulness of hydro-fracturing to the development of groundwater resources and to demonstrate that the technique has a place in the supply of good drinking water to rural communities in some parts of the country where groundwater is the major source of water supply.

\section{The Study Area}

The study was carried out in three districts in the Volta Region, namely, the Adidome, Akatsi and the Ho Districts. The area covered by the districts is located within Longitudes $0^{\circ} 8^{\prime} \mathrm{W}$ and $1^{\circ} 0 \mathrm{E}$ and Latitudes 5 ${ }^{\circ} 55^{\prime} \mathrm{N}$ and $6^{\circ} 55^{\prime} \mathrm{N}$ (Fig. 1). The main vegetation 


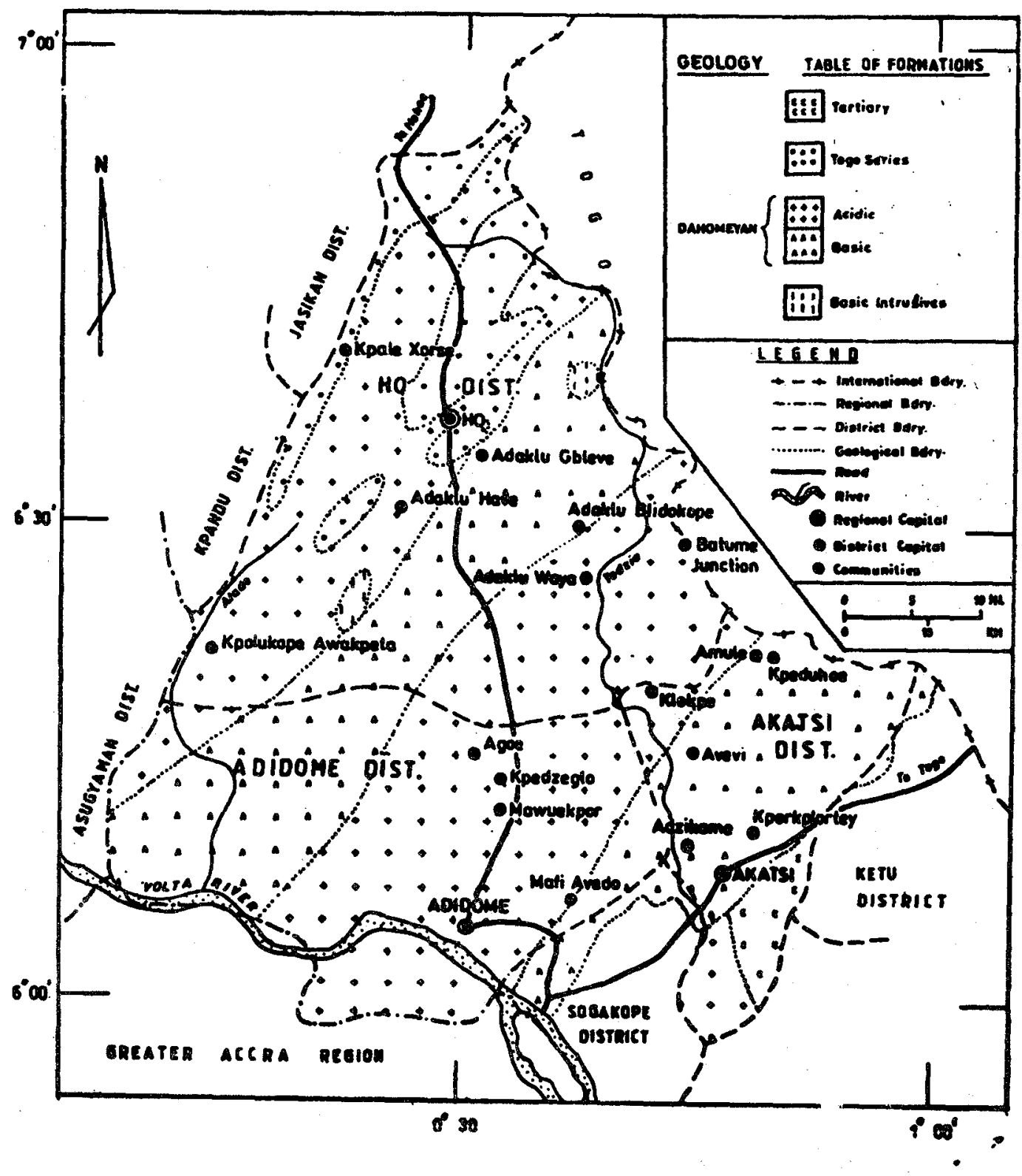

Fig. 1: Location map of study area, also showing Geological formations 
types of the area are savannah and moist deciduous forests. Climate in this part of the country is strongly influenced by the South West Monsoons and the North East Trade Winds. In general, peak rainfall in the area occurs in June/July and September/October. Between November and March/April, rainfall is generally low accounting for only $19-28 \%$ of the annual value [Anon, 1993]. The mean annual rainfall in the area is between $1000 \mathrm{~mm}$ and $1400 \mathrm{~mm}$.

The mean air temperature is $27.3^{\circ} \mathrm{C}$, with the highest mean monthly value of $30^{\circ} \mathrm{C}$ occurring in January/ February when the duration of sunshine is long, cloud cover is less and the effect of the Harmattan is very severe. The mean monthly relative humidity increases from between $64 \%$ and $74 \%$ in January to a maximum of about $87 \%$ in June. The mean monthly evaporation is estimated to be about $140 \mathrm{~mm} / \mathrm{month}$ [Anon, 1993].

\section{Geology}

The Dahomeyan formation, the Togo Series and Mafic intrusives underlie the project area. Deposits of unconsolidated sand, clay and gravel which are Recent can also be found in certain parts of the area. There are also deposits from the Eocene and Cretaccous eras, as well as Tertiary deposits composed of red continental soils mainly ilmenitic sand, sandy clay and gravel [Kesse, 1985]. The Dahomeyan formation is composed mainly of ortho-and para-gneisses, schists and migmatite many of which are rich in garnet, hornblende and biotite. The rocks of Togo Series consist mainly of quartzite, sandstones, shales, phyllites, schists and some silicified limestone. The predominant rocks forming the Mafic intrusives are dolerite, norite and gabbro.

\section{Groundwater Occurrence}

The basement rocks have very little intergranular porespace and are thus characterized by negligible primary porosity and permeability. Where the rocks occur near the surface, they are usually fractured, weathered and acquire some significant secondary porosity. The main avenues of groundwater supply to the rocks are thus the weathered layer or regolith developed on the crystalline basement rocks and fractures within the bedrock.

The aerial extent, thickness and physical character of the weathered zone varies from place to place and may range from a few metres on hilly terrains to about 40 metres in valley areas. Water is encountered in the fractures or fracture zones with saturated regolith rather than from extensive aquifers. Where the saturated regolith is thin or absent, sufficient permeability has to be identified in the fractured bedrock. Groundwater occurrence and yield of wells are thus strongly dependent on the degree of bedrock fractures and the extent of their interconnection, and the extent and nature of weathering.
The Dahomeyan formation, which underlies the areas around $\mathrm{Ho}$ is generally massive with few joints or fractures. The crystalline gneiss, schist and migmatites weather into clay and clayey sand, which are usually impervious and hence limit the availability of groundwater [World Vision International, 1997]. However, where definite discontinuities are encountered good yield of water may occur in wells penetrating such jointed zones.

\section{HYDRO-FRACTURING PROCEDURE Pre-hydrofracturing investigation}

At the pre-hydro fracturing investigation stage, resistivity measurements were carried out along the depth profile of each well using the 16" (16 inches) short normal and 64" (16 inches) long normal resistivity method to identify potential fracture zones within the rock formation. Results obtained from the measurements were then correlated with the existing driller's borehole logs to delineate specific fracture zones that can serve as targets for packer settings in the hydrofracturing technique.

The equipment used for the pre-hydrofracturing investigation is the SAS LOG 200 Terrameter. It consists of a $200-\mathrm{m}$ long logging cable with a logging probe, a 6-position MODE sclector and circuitry for connecting an SAS $300 \mathrm{C}$ resistivity measuring device, a current return electrode and a potential reference electrode. Resistivity measurements were taken at intervals of one (1) meter within the submerged portions of the boreholes beginning from the bottom and working upwards to locate the position of fractures or joints within the borehole profile. Fig. 2 is a characteristic resistivity profile of a borehole showing the location of a fracture zone within the bedrock.

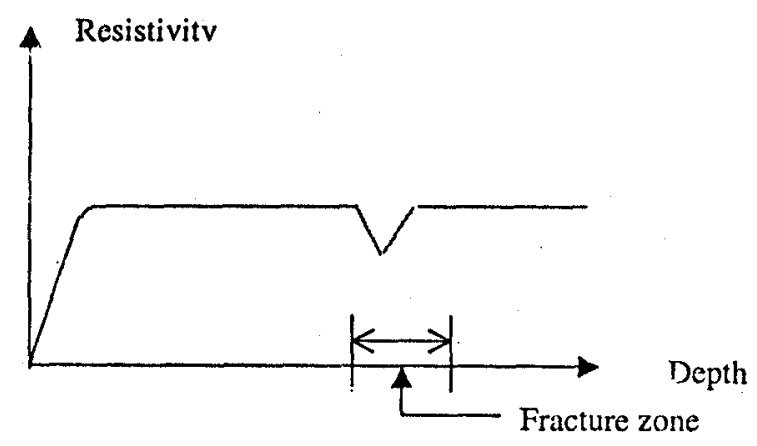

\section{Fig. 2. Borehole resistivity profile}

The presence and depths of discontinuities within the rock formation were determined by means of such plots. After the resistivity logging, a one-hour pumping test was then carried out to ascertain the borehole's yield and to establish baseline hydraulic characteristics of the aquifer to provide the basis for evaluating the success rate of the exercise. 


\section{Hydro-fracturing operation}

The equipment used for the operation was made up of a high-pressure water pump, a packer unit, steel pipes and a hydraulic oil pump to induce pressure on the packer. The hydraulic oil pump used could provide a pressure of 200 bars. The water pump could deliver a pressure of up to 150 bars with a maximum discharge of $1151 / \mathrm{min}$. The packer unit was a single packer system with a packer length of $1.2 \mathrm{~m}$ and a release diameter of $125 \mathrm{~mm}$ [World Vision International, 1997]. A drilling rig (Smith Capital) was used as a crane for installing the packer at the required depth. A water tanker with 13,500 litres ( 3000 gallons) capacity was used to inject water during the operation.

The operation began by positioning the packer in a manner such that the targeted fracture zone would be captured to allow water under high pressure to be injected. The position of the packer was determined based on results of the resistivity log of the borehole correlated with existing drilling logs. To make water injection effective, a high pressure was induced in the packer to render the room with which injection would take place water-tight. Water was then injected under a gradually increasing pressure until a maximum value was attained. The maximum water pressure was then sustained until it began to drop, indicating the successful opening of target fracture or joint.

\section{Post hydro-fracturing pumping test}

Each borehole was pumped at a constant rate for a period of six hours. The pumping rate adopted was selected from the initial pre-testing information and ranged between $9.0 \mathrm{l} / \mathrm{min}$ and $40.0 \mathrm{l} / \mathrm{min}$. During the test pumping, water levels were measured every minute for the first 10 minutes, then subsequently every 5 minutes for the next 50 minutes, then every 15 minutes for next two hours, and thereafter every 30 minutes for the remaining three hours of the test. After the pumping was completed each borehole was allowed to recover and the water levels monitored for 3 hours as follows; every minute for the first 10 minutes, then every 5 minutes for next fifty minutes, and thereafter every 15 minutes for the remaining two hours of the test.

\section{RESULTS}

The pumping test data for the boreholes before and after the hydrofracturing technique and the increase in borehole yicld resulting from the hydrofracturing operation are detailed below for the Adidome, Akatsi and Ho districts in Table 1, Table 2, and Table 3, respectively.
Expressing the yicld increase on the basis of specific capacity and not discharge takes into account the extent and effect of drawdown on well performance and therefore provides a better indication of the sustainability of the wells as water was being drawn from them.

\section{DISCUSSION}

For any borehole, the target of the application of the hydro-fracturing technique was to attain a minimum well yield of $13.51 / \mathrm{min}$ in order to justify hand pump installation. In order to provide a quick assessment of the impact of the technique on well yield, the performance of the boreholes for which pre-and post hydrofracturing yield data were available has been summarized in Table 4. The table details for each district the number of boreholes falling within a specific range of yield increase.

\section{Boreholes in the Adidome District}

The results of the pumping tests indicate that almost all the boreholes in the Adidome District responded positively to the hydro-fracturing technique and showed increase in yield though to different degrees except one (B01) located at Agoe. Exceptional increase in specific capacity of over 2,000\% was recorded for one borehole at Mawuekpor. Two other boreholes in the district also showed substantial increase in yield (above $200 \%$ ). Three out of the seven boreholes considered in the district, which showed yield increase below $100 \%$, two of them actually had specific capacity increase below $50 \%$ of its pre-hydrofrac value. It is thought that the degree of fracture interconnectivity within the bedrock may be rather low and poor for those borcholes with low response. On the whole, however, the improvements achieved for all the boreholes, except one, put their yields at levels that could sustain hand pump abstraction rates.

\section{Boreholes in the Akatsi District}

A total of thirteen boreholes were considered in this district. As seen from the data summary in Table 4, two boreholes in the district- E220 at Adzikame and E110 at Avevi (Table 2) increased in specific capacity in excess of $1,500 \%$. It is also seen from the summary that five of the thirteen boreholes considered in the district showed at least five-fold increase in specific capacity on application of the hydrofracturing technique. The response of five other boreholes was rather poor with three of them showing only marginal increase (less than $50 \%$ ) in specific yicld capacity. However, based on the minimum yield criteria and the overall results, all boreholes were considered suitable for hand pump installation. 
Table 1: Pre-and post-hydrofrac pumping test data for the Adidome District

\begin{tabular}{|c|c|c|c|c|c|c|c|c|c|}
\hline \multirow[t]{2}{*}{ Community } & \multirow{2}{*}{$\begin{array}{l}\text { B/H } \\
\text { ID No. }\end{array}$} & \multirow{2}{*}{$\begin{array}{r}\text { B/H } \\
\text { Depth }\end{array}$} & \multicolumn{2}{|c|}{$\begin{array}{l}\text { Discharge } \\
\text { (I/min) }\end{array}$} & \multicolumn{2}{|c|}{$\begin{array}{c}\text { One hour } \\
\text { Drawdown }(m)\end{array}$} & \multicolumn{2}{|c|}{$\begin{array}{c}\text { Specific Capacity } \\
\left(\mathrm{m}^{\prime} / \mathrm{h} / \mathrm{m}\right)\end{array}$} & \multirow{2}{*}{$\begin{array}{c}\text { Yicld } \\
\text { increased } \\
\%\end{array}$} \\
\hline & & & Pre- & Post- & Pre- & Post- & Pre- & Post & \\
\hline \multirow[t]{2}{*}{ Mafi Avedo } & $\mathrm{BO} 01$ & 59 & 13.5 & 22.5 & 14.12 & 6.21 & 0.006 & 0.21 & 250 \\
\hline & $\mathrm{BO} 2$ & 54.9 & 18.0 & 22.5 & 8.57 & 1.47 & 0.13 & 0.92 & 608 \\
\hline Kpedzeglo & $\mathrm{BO4}$ & 36.6 & 9.0 & 9.0 & 18.81 & 11.8 & 0.03 & 0.05 & 67 \\
\hline \multirow{2}{*}{ Mawuekpor } & $\mathrm{BO1}$ & 600 & 102 & 13.5 & 25.18 & 19.58 & 0.02 & 0.04 & 100 \\
\hline & $\mathrm{BOB}$ & 600 & 113 & 18.0 & 21.03 & 1.53 & 0.03 & 0.71 & 2,267 \\
\hline \multirow[t]{2}{*}{ Agoe } & $\mathrm{B} 01$ & 603 & 90 & 13.5 & 20.32 & 23.54 & 0.03 & 0.03 & 0 \\
\hline & $\mathrm{BOB}$ & 585 & 102 & 13.5 & 24.69 & 19.34 & 0.03 & 0.04 & 33 \\
\hline
\end{tabular}

Source: WRI, 1997; 1998

Table 2: Pre-and post-hydrofrac pumping test data for the Akatsi District

\begin{tabular}{|c|c|c|c|c|c|c|c|c|c|}
\hline \multirow[t]{2}{*}{ Community } & \multirow{2}{*}{$\begin{array}{c}\text { B/H } \\
\text { ID No. }\end{array}$} & \multirow{2}{*}{$\begin{array}{c}\text { B/H } \\
\text { Depth }\end{array}$} & \multicolumn{2}{|c|}{$\begin{array}{l}\text { Discharge } \\
\text { (I/min) }\end{array}$} & \multicolumn{2}{|c|}{$\begin{array}{c}\text { One hour } \\
\text { Drawdown (m) }\end{array}$} & \multicolumn{2}{|c|}{$\begin{array}{c}\text { Specific Capacity } \\
\left(\mathbf{m}^{\prime} / \mathbf{h} / \mathbf{m}\right)\end{array}$} & \multirow{2}{*}{$\begin{array}{l}\text { Yield } \\
\text { increased } \\
\%\end{array}$} \\
\hline & & & Pre- & Post- & Pre- & Post- & Pre- & Post & \\
\hline \multirow{3}{*}{ Amule } & 160 & 47.8 & 8.0 & 20.0 & 18.34 & 8.10 & 0.03 & 0.15 & 400 \\
\hline & $\mathrm{C} 70$ & 52.8 & 5.5 & 15.0 & 10.33 & 9.98 & 0.03 & 0.09 & 200 \\
\hline & $\mathrm{C} 120$ & 46.7 & 6.0 & 14.0 & 9.74 & 13.34 & 0.04 & 0.07 & 75 \\
\hline Kpeduhoe & E65 & 43.4 & 5.5 & 14.0 & 14.54 & 9.77 & 0.02 & 0.9 & 350 \\
\hline \multirow[b]{2}{*}{ Klokpe } & $\mathrm{A} 100$ & 47.8 & 6.0 & 14.0 & 2.87 & 4.62 & 0.13 & 0.8 & 38.5 \\
\hline & $\mathrm{G} 220$ & - & 8.0 & 14.0 & 2.86 & 3.41 & 0.17 & 0.25 & 47.1 \\
\hline \multirow[b]{2}{*}{ Kporkplorte } & $\mathrm{C} 105$ & 65.3 & 5.5 & 15.0 & 13.61 & 5.10 & 0.02 & 0.6 & 700 \\
\hline & $\mathrm{A} 300$ & 65.0 & 6.0 & 14.0 & 13.13 & 2.70 & 0.03 & 0.31 & 933.3 \\
\hline \multirow{3}{*}{ Adzikame } & E180 & - & 5.0 & 15.0 & 2.72 & 7.18 & 0.11 & 0.13 & 18.2 \\
\hline & E220 & 61.7 & 7.5 & 15.0 & 12.68 & 1.37 & 0.04 & 0.66 & 1,550 \\
\hline & $\mathrm{C} 50$ & 59.6 & 6.0 & 14.0 & 17.07 & 6.84 & 0.02 & 0.12 & 500 \\
\hline \multirow[b]{2}{*}{ Avevi } & D50 & 57.7 & 5.5 & 14.0 & 8.59 & 12.21 & 0.04 & 0.07 & 75 \\
\hline & E11 & 42.7 & 6.0 & 18.0 & 8.48 & 1.43 & 0.04 & 0.76 & 1800 \\
\hline
\end{tabular}

Source: Horatio-Larbie and Asare, 1998 


\begin{tabular}{|c|c|c|c|c|c|c|c|c|c|}
\hline \multirow[t]{2}{*}{ Community } & \multirow{2}{*}{$\begin{array}{l}\text { B/.H ID } \\
\text { No }\end{array}$} & \multirow{2}{*}{$\begin{array}{l}\text { B/.H } \\
\text { No }\end{array}$} & \multicolumn{2}{|c|}{$\begin{array}{l}\text { Discharge } \\
(\mathrm{I} / \mathrm{min})\end{array}$} & \multicolumn{2}{|c|}{$\begin{array}{c}\text { One hour } \\
\text { Drawdown (m) }\end{array}$} & \multicolumn{2}{|c|}{$\begin{array}{c}\text { Specific Capacity } \\
\left(\mathrm{m}^{\prime} / \mathrm{h} / \mathrm{m}\right)\end{array}$} & \multirow{2}{*}{$\begin{array}{c}\text { Year } \\
\text { increase } \\
\quad(\%)\end{array}$} \\
\hline & & & Pre- & Post- & Pre- & Post & Pre- & Post- & \\
\hline $\begin{array}{l}\text { Adaklu } \\
\text { Blidokope }\end{array}$ & $\mathrm{B} 02$ & 59.3 & - & 15.0 & - & 5.2 & & & - \\
\hline Adaklu & $\mathrm{B} 01$ & 60.9 & 9.0 & 10.0 & 12.5 & 13.7 & & & 2.3 \\
\hline Gbleve & $\mathrm{B} 02$ & 536 & 90 & 16.0 & 9.9 & 8.2 & & & 116.7 \\
\hline \multirow{2}{*}{$\begin{array}{l}\text { Adaklu } \\
\text { Have }\end{array}$} & $\mathrm{B} 01$ & 58.4 & 9.0 & 10.0 & 22.2 & 16.6 & & & 50.0 \\
\hline & $\mathrm{BO} 03$ & 58.5 & 9.0 & 13.0 & 19.0 & 19.0 & & & 31.7 \\
\hline \multirow{4}{*}{$\begin{array}{l}\text { Adaklu } \\
\text { Waya }\end{array}$} & $\mathrm{B} 01$ & 60.0 & 9.0 & 12.0 & 17.5 & 23.0 & & & 0 \\
\hline & $\mathrm{B} 02$ & 529 & 9.0 & 12.0 & 25.5 & 230 & & & 14.3 \\
\hline & $\mathrm{B} 03$ & 60.6 & 9.0 & 10.0 & 25.8 & 25.8 & & & 14.3 \\
\hline & $\mathrm{BO} 4$ & 59.9 & 9.0 & 9.0 & 20.8 & 16.6 & & & 26.9 \\
\hline \multirow{3}{*}{$\begin{array}{l}\text { Batume } \\
\text { Junction }\end{array}$} & $\mathrm{BO1}$ & 59.7 & 9.0 & 40.0 & 13.8 & 3.3 & & & $1,769.2$ \\
\hline & $\mathrm{BCR}$ & 550 & 9.0 & 13.0 & 26.2 & 3.3 & & & $1,038.1$ \\
\hline & $\mathrm{BOB}$ & 543 & 9.0 & 10.0 & 20.2 & 15.3 & & & 44.4 \\
\hline Kpale Xorse & $\mathrm{B} 01$ & 45.7 & 9.0 & 15.0 & 26.2 & 21.7 & & & 100.0 \\
\hline $\begin{array}{l}\text { Kpolukope } \\
\text { Awckpeta }\end{array}$ & $\mathrm{BOC}$ & 61.1 & 9.0 & 16.0 & 9.7 & 10.2 & & & 70.9 \\
\hline Shia & $\begin{array}{l}\mathrm{BO1} \\
\mathrm{BOC} \\
\mathrm{BOB}\end{array}$ & $\begin{array}{l}55.9 \\
59.3 \\
58.0 \\
\end{array}$ & $\begin{array}{l}9.0 \\
9.0 \\
9.0 \\
\end{array}$ & $\begin{array}{l}16.0 \\
10.0 \\
10.0 \\
\end{array}$ & $\begin{array}{l}- \\
- \\
-\end{array}$ & $\begin{array}{r}1.7 \\
16.6 \\
12.6 \\
\end{array}$ & $\begin{array}{l}- \\
- \\
-\end{array}$ & $\begin{array}{l}0.571 \\
0.038 \\
0.048 \\
\end{array}$ & $\begin{array}{l}- \\
- \\
-\end{array}$ \\
\hline
\end{tabular}

The increase in borehole yield has been expressed on the basis of the specific capacity of the wells as

$\%$ Yield Increase $=100$ [(Specific Capacity) ${ }_{\text {after }}$-(Specific Capacity) $\left.{ }_{\text {before }}\right]$ (Specific Capacity) ${ }_{\text {before }}$

Table 4. Range of increase in borehole specific capacity after hydrofracturing

\begin{tabular}{|c|c|c|c|}
\hline Increase in Specific Capacity & \multicolumn{3}{|c|}{ Number of boreholes } \\
\cline { 2 - 4 }$(\%)$ & Adidome & Akatsi & Ho \\
\hline$<100$ & 3 & 5 & 9 \\
$100-500$ & 2 & 3 & 2 \\
$500-1,000$ & 1 & 3 & 0 \\
$>1,000$ & 1 & 2 & 2 \\
Total & 7 & 13 & 13 \\
\hline
\end{tabular}




\section{Boreholes in the Ho District}

Boreholes located in the Ho District showed mixed response to the hydrofracturing technique (Table 3 ). Even though two boreholes at Batume (BO1 and $\mathrm{BO} 2)$ increased in specific capacity in excess of $1,000 \%$, majority of the boreholes registered increases that were below $100 \%$, with some boreholes being unresponsive (BO1 at Adaklu Waya and BO1 at Adaklu Gbleve). Assessment of yield improvements could not be made for four boreholes due to lack of pre-hydrofrac data. Generally, the response of the boreholes in the Ho District was less encouraging than those in the other districts. However, in spite of this, the post hydrofrac specific capacity values qualified all the wells for hand pump installation except in the case of two boreholes that had to be abandoned due to their rather poor response.

\section{CONCLUSION}

This paper has presented and discussed hydraulic data on wells located in the Akatsi, Ho and Adidome Districts in the Southern part of the Volta Region to which hydrofracturing technique was applied. The application of the technique was to increase the yield of the wells for the supply of potable water to communities in the districts.

The results show that out of 37 boreholes to which the hydro-fracturing technique was applied, as many as 35 increased in yields to levels ranging between 10 and $2,000 \%$. The success of the operation made it possible for hand pumps to be installed on practically all the wells for water abstraction including those that initially were dry or marginal in yield and which otherwise would have been abandoned.

The response of the boreholes in the Ho District to the hydro-fracturing technique was less encouraging than those boreholes in the other districts. It is thought that perhaps the geologic formation serving as groundwater aquifer in that district may have suffered less discontinuity within it than those in the other districts. The overall success of the operation is a practical demonstration of the usefulness of hydro-fracturing methods to groundwater resources development in some parts of the Volta Region of Ghana.

\section{References}

1. Anon. (1993). Royal Danish Embasy's, Inventory and Assessment of Perennial Springs and Streams in the Volta Region, Final Report of Rural Drinking Water Supply and Sanitation Project in the Volta Region. Vol.I - Main Report, Aug. 1993.

2. Kesse, G. O. (1985). The Mineral and Rock Resources of Ghana, Published by A. A. Balkema, Rotterdam/Boston.

3. WRI, (1997). Borehole Drilling Supervision in Ho District (Phase II), CWSD (VRWSSP), July 1997.

4. World Vision International (1997). Unihydro, Adaklu Anfoe Hydrofrac Supervision Report, Supervision of World Vision International Borehole Hydrofracturing contract at Adaklu Anfoe in Ho District, Report prepared for Regional Coordinator/ Programme Manager, VRCWSP, Ho.

5. WRI, (1997). Hydrogeological Services for Hydrofracturing of Boreholes, Phase I: Borehole Logging and Pre-Hydrofracturing Pumping Test. Consultancy Report submitted to VRWSSP.

6. WRI, (1998). Hydrogeological Services for Hydrofracturing of Boreholes, Phase II: PostHydrofracturing Pumping Test-A Progress Report, Consultancy Report submitted to VRWSSP.

7. Horatio-Larbie, G.and Asare, E. B. (1998). Effect of Hydrofracturing on Borehole Yields- A Case Study in the Southern part of Volta Region, in Advances in Groundwater Exploration and Development in Ghana, Proceedings of a seminar organized by the Department of Geology, University of Ghana in collaboration with Geological Institute, University of Copenhagen under the auspices of the DANIDA ENRECA Hydrogeological Project, October 22-23,1998.

8. Unihydro, (1998). Hydrofrac and Post-Testing of Marginal Boreholes in Ho District, Report prepare for Regional Director/Programme Manager, Volta Region Community Water Supply Programme, Ho, February 1999. 